\title{
THE DYNAMICS OF SPIRITUALITY IN THE OLD AGE: THE PERSPECTIVE OF MAQASHID AL-SHARIAH AND PSYCHOLOGY
}

\author{
Mubasirun \\ Institut Agama Islam Negeri Salatiga \\ Pulutan, Salatiga, Jawa Tengah, Indonesia, 50716 \\ E-mail:mubasirun@iainsalatiga.ac.id \\ Sa'adi \\ Institut Agama Islam Negeri Salatiga \\ Pulutan, Salatiga, Jawa Tengah, Indonesia, 50716 \\ E-mail: ssaadidr@gmail.com
}

\begin{tabular}{c|c|c}
\hline Received: & Revised: & Approved: \\
$10 / 05 / 2021$ & $15 / 06 / 2021$ & $22 / 06 / 2021$ \\
\hline
\end{tabular}

DOI : https:// doi.org/10.32332/akademika.v26i1.3281

\section{(). (1) ()}

The Dynamics of Spirituality in the Old Age: The Perspective of Maqashid Al-Shariah and Psychology Licensed Under a Creative Commons Attribution-ShareAlike 4.0 International License

\begin{abstract}
This study aimed to describe the dynamics of spirituality among the retirement community viewed from the perspective of Maqashid al-Shari'ah and Psychology that are the factors that cause the strengthening of the activities of the spirituality to liberate itself from the situation of post-power syndrome. In-depth interviews and observations, data reduction, data presentation, and verification are the mainstay methods in the data collection and analysis of this study. The results of this study show that the mashlahah (benefit) that is the meeting point between the theory of Maqashid alShari'ah and Psychology become a basic need for the retirement community. In their old age, the retirement community precisely strengthens their spirituality. The strengthening factors of their spirituality are the motivation of the fulfillment of the needs of the world and hereafter, free of social conflicts, as well as the awards and respect from their surrounding community because of their devotion and example (social devotion and leadership).
\end{abstract}

Keywords: Spirituality, Maqashid Al-Shariah, Psychology

\section{A. Introduction}

Not many government workers can accept the idea that they must leave their formal occupations and positions when they retire. Retirement is a new position in a person's life when they leave their official job, and it results in economic decline in the form of lower income than before. As a result, mental preparedness is required to deal with societal change, as well as excellent self-acceptance to prevent depression, 
dissatisfaction, and stress.

For some people, retirement is a situation that requires a variety of treatments in the shape of different activities. This is because, during this period, people aspire to attain multiple life goals, but due to age-related factors, these objectives are frequently unbalanced. According to Atkinson, et $\mathrm{al}^{1}$, as quoted by Jalaluddin, humans reach the zenith of their most productive age span between the ages of 40 and 65 . However, there is a psychological crisis at this age owing to an internal struggle between the urge to rise and the urge to fall. This tendency enables persons of this age to pay close attention to important societal issues and to help the younger generation. As a result, it's unsurprising that retirees are seeking for ways to spend their free time when they retire. Retirement is seen unfavorably by retirees due to the loss of tenure, employment, and formal activities in the job, despite the fact that retirement is a fantastic opportunity to better one's life before old age arrives. Retirees can occupy their free time with a variety of worthwhile activities while also helping others.

The transition from regular work to unemployment and reduced income will undoubtedly generate anxiety in a retiree, particularly for those who have family dependents such as children who still require a significant amount of money, so they will feel the burden of life growing when they retire. According to Santrock, persons in their forties and fifties should begin planning for retirement, both financially and psychologically ${ }^{2}$. In late adulthood, establishing and satisfying leisure activities are vital elements of preparedness. The transition from employment to retirement may be less stressful if a late adult establishes leisure interests that can be continued after retirement. Of course, facing retirement necessitates retirement preparedness, not only in terms of social, financial, physical, and mental maturity but also in terms of spiritual development, to prepare for numerous retirement options.

Spirituality is needed by individuals to build meaning for their life experiences, as well as unique beliefs to provide extraordinary meaning to life's realities. Religion will be able to guide people to accept their situations with real acceptance. These circumstances enable people to redefine their life by creating preparations for every eventuality to accomplish a certain objective in the future ${ }^{3}$. Spirituality, according to Robert A Emmons, can help people address a variety of challenges in life. Spirituality can help people re-prioritize their aims in life. Even spiritual individuals are easier to adjust to when confronted with adversity. They are also better able to discover meaning in every event and receive instructions on how to proceed ${ }^{4}$. This is in line with the findings of Satria \& Fakhrurrozi, who discovered that many changes experienced by a person in retirement, such as changes in economic status, the removal of many facilities, and many reduced activities carried out by subjects, particularly activities related to work. Having a high level of spirituality, on the other hand, will be able to give psychological well-being, as evidenced by behaviors such as being able to be friendly with everyone, keeping connected to the environment, being creative, and so on. This might happen if the person has the will and drive to grow closer to God and create better conduct than he did previously. Based on this context, this research is carried out on the subject of the retirement community in Salatiga and Semarang

${ }^{1}$ Jaladuddin, Psikologi agama (Jakarta: Rajawali Press, t.t.).

2 J.W. Santrock,. Perkembangan Masa Hidup (Jakarta: Erlangga, 2002).

${ }^{3}$ Deleyner Nejdet, "Religious Contrasts in Consumer Decision Behaviour Patterns: Their Dimensions and Marketing Implications," European Journal of Marketing 28, no. 5 (t.t.): 36-53.

${ }^{4}$ Muzakkir, "Kesiapan Diri Menghadapi Masa Pensiun Ditinjau Dari Aspek Spiritual," Al-Kaffah-Jurnal Kajian Nilai-Nilai Keislaman 8, no. 1 (t.t.): 1-27. 
Regency, Central Java, with the title The Dynamics of Spirituality in the Old Age: the Perspectives of Maqashid al-Shari'ah and Psychology, to answer problems: How are the dynamics of spirituality among retired community members in Salatiga and the Semarang Regency viewed through the lens of Maqashid al-Shari'ah and psychology?, What factors contribute to the development of spirituality in the old age?, What activities do retired community do to spend their days now after entering the retirement period?.

Many studies on the spirituality and mental health of retirees have been undertaken, like the study The Difference in Depression Levels between Retired Civil Servants Who Work and Those Who Don't Work by Mahendra Arma Sani. Using an analytical observational method with a cross-sectional approach, this study attempted to discover and evaluate variations in depression levels between retired government officials who work and those who do not. The BDI questionnaire was utilized by 67 retired public officials who were selected using a total sampling technique. The statistical test used was the Chi-Square test. The results of the data analysis showed that the value of $\mathrm{p}(\mathrm{sig})$ is $0.000(\mathrm{p}<0.05)$. According to the findings, there was a difference in depression levels among retired governmental servants who did not work and those who did.

The other study, titled Spiritual Intelligence with Anxiety Facing Retirement, was conducted by Danar Lesmana from the University of Muhammadiyah Malang. The goal of this study is to see if there's a link between spiritual intelligence and retirement anxiety. This is a quantitative descriptive study. Purposive sampling was utilized as the sampling methodology, using 64 public workers as subjects. Pearson's productmoment correlation was used as the analytic methodology. According to the findings of this study, spiritual intelligence and retirement anxiety have a strong negative link $(\mathrm{r}=0.734 ; \mathrm{p} / \mathrm{sig}=0.000)^{5}$. Next, Firna Dwi Putri et al's study The Prevalence of Depression in Retired Civil Servants Taking Retirement Funds at BTPN Bank in M. Yamin Padang Branch Office, is a qualitative descriptive study that aims to determine the prevalence of depression in retired civil servants who took retirement funds at BTPN Bank in M. Yamin Padang Branch Office. According to the findings, group of III/a retirees had the highest frequency of depression after 10 years of retirement ${ }^{6}$.

Even though the three studies all focus on the retirement community, the research we do differs significantly from the three studies in terms of the study's focus, object, theoretical framework, and methodological features. Because the study we are conducting is qualitative, we'll use a qualitative approach to collect data, starting with determining the research theme, planning, types of data collected, methods used, selecting informants, and analyzing models. We'll use in-depth interviews as the primary data collection method, in addition to observation and documentation. According to Creswell, the qualitative technique is designed to generate an in-depth examination of the key phenomena rather than generalize to the broader population? The qualitative methodology was chosen because the data required for researchers to have a thorough understanding of the respondent's perspective on social issues

5 Danar Lesmana, "Kecerdasan Spiritual Dengan Kecemasan Menghadapi Masa Pensiun," JIPT: Jurnal Ilmiah Psikologi Terapan, Januari, 02, no. 1 (2014): 16.

6 Finna Dwi Putri, Amel Yanis, dan Elmatris Syamsir, "Prevalensi Depresi pada Pensiunan Pegawai Negeri Sipil yang Mengambil Dana Pensiun di Bank BTPN Cabang M. Yamin Padang," Jurnal Kesehatan Andalas 4, no. 2 (1 Mei 2015), https://doi.org/10.25077/jka.v4i2.258.

7 John W Creswell, Qualitative Inquiry and Research Design Choosing Among Five Tradition (London: Sage Publication, 2007). 
necessitated it. The qualitative method is well suited to the sort of data gathered and the endeavor to decipher complicated social phenomena. Researchers must use the case study approach to qualitatively investigate data from informants as part of the research subject. The case study is seen to be the best option for a qualitative method that is limited in scope to the theme within the research's time (March-November 2020). Because the scope of this study is intentionally limited to spiritual activities in retirement communities, the case study approach used is critical ${ }^{8}$.

\section{B. The Perspective of Maqashid Al-Shari'ah}

In terms of linguistics, Maqashid al-Shari'ah is made up of two words: Maqashid and Shari'ah. Maqashid is the plural form of maqshad, which originates from the root word qashada yaqshudu qashdan, which means deliberate or purposeful ${ }^{9}$. In terms of linguistics, the word Shari'ah has several connotations, including the route to the water ${ }^{10}$ and the straight path ${ }^{11}$. Meanwhile, Shari'ah refers to all that Allah requires of His slaves in terms of aqidah, worship, morality, and muamalat, as well as all systems that govern human existence for the profit and pleasure of mankind in this world and the hereafter ${ }^{12}$. Maqashid al-Shari'ah terminology is not present in salaf literature. Indeed, Shari'ah is the purpose to accomplish the benefit of mankind in this world and the next," said Abu Ishaq al-Syathibi, who is regarded a Maqashid scientific pioneer ${ }^{13}$. The law, which consists mostly of commands and prohibitions, is enacted for the good of all humans ${ }^{14}$. Al-Syathibi also did not complete the definition of Maqashid al-Shari'ah in his work al-Muwafaqat. Only in the era of contemporary scholars like Thahir Ibn 'Asyur did the etymological understanding of Maqashid al-Shari'ah emerge, with the understanding that Maqashid al-Shari'ah is values and wisdom that are the goals of Shari'ah in all or most of God's law, with some of these objectives not only applying to Sharia law products in particular ${ }^{15}$. Maqashid al-Shari'ah, according to 'Ilal al Fasi, is the purpose of sharia and the secret of every law of Allah' ${ }^{16}$. Maqashid al-Shari'ah, on the other hand, is defined by Ahmad al-Hajj al-Kurdi as values that are the objective of constructing law ${ }^{17}$.

According to certain interpretations of Maqashid al-Shari'ah, the principle of Maqashid al-Shari'ah is the law of God, and its goal is the benefits/mashlahah behind all of God's orders and prohibitions. Those benefits become basic human needs. Imam alSyathibi emphasized the needs on protecting religion/hifdhu al-diin, guarding the

\footnotetext{
${ }^{8}$ Creswell, Qualitative Inquiry and Research Design Choosing Among Five Tradition: 74-79. t.t.):766.

${ }^{9}$ Majma' al-Lughah al-'Arabiyyah al-Mu'jam al-Wasith (Istanbul: Al-Maktabah al-Islamiyah,

10 Muhammad, Jamaludin Ibn Al-Mukarram Ibn al-Manzur, Lisan Al Arab, 8 (Mesir: alMu'assasah al-Misriyyah al-'Ammah li al-Ta'lif wa al-Anba' wa al-Nashr, t.t.):175.

${ }^{11}$ Muhammad Mustafa al-Syalabi, al-Madkhal fi al-Ta'rif bi al-Fiqh al-Islāmi (Beirut: Dar alNahdhah al-'Arabiyyah, 1983)::27.

12 Manna al-Qatan, Tãrikh al-Tasyri' al-Islami (Beirut: Mu'assasat al-Risalah, 1996):15.

13 Abu Ishaq Al-Syatibi, al-Muwafaqat fi Ushul al-Syariah, 1 (Beirut: Dar al-Ma'rifah, 1996):350.

14 Al-Syatibi,.

${ }^{15}$ Ibn 'Asyur Muhammad al-Thahir, Maqashid Al-Syari'ah Al-Islamiyah (Tunisia: Mashna' Al-Kitab, t.t.):51. Risalah, 1979).

16 'Ilal 'Al-Fasi, Maqashid Al-Syari'ah Al-Islamiyah Wa Makarimuha (Maroko: Mathba'ah Al-

17 Abu Ishaq Al-Syatibi, al-Muwafaqat fi Ushul al-Syariah, 1 (Beirut: Dar al-Ma'rifah, 1996), hlm. 326 .
} 
soul/hifdhu al-nafs, keeping reason/hifdhu al-aql, preserving descendant/hifdhu al-nasl, and preserving property/hifdhu al-mal ${ }^{18}$. The benefits that al-Syathibi emphasizes are divided into two categories: physical and spiritual needs. The benefit of the property and the benefit of descendants are included in physical needs, whereas spiritual needs include theological benefit: the benefit of reason/mashlahah al-Aql, and the benefit of the soul/mashlahah al-Nafs. Physical needs lead to worldly advantages, while spiritual advantages lead to uhkrowi advantages. Maqashid al-Shari'ah functions as a catalyst for future reforms toward a more constructive and humane society ${ }^{19}$.

\section{The Perspective of Psychology}

According to contemporary psychological studies, people have some dimensions: physical, spiritual/ruhaniyah and spiritual dimensions ${ }^{20}$. Those dimensions cannot work independently. It must work together for all dimensions to be balanced. Humans are no different from animals if they solely consider the physical aspects ${ }^{21}$. The three's connection must be balanced to build a harmonious partnership ${ }^{22}$. The three of them cannot go alone since they would not be able to achieve their goals. As a result, spirituality becomes the most significant aspect of human life. Giving charity, praying, paying zakat, going on pilgrimages, and Jihad in wars are all spiritual needs that arise exclusively from religious motivation and devotion to God ${ }^{23}$.

Self-actualization, according to Abraham Maslow, is not the ultimate need: rather, there is something greater, namely self-transcendence, which means that life has a greater purpose than itself ${ }^{24}$. Perhaps Maslow was referring to the urge to attain religious life's aim, which is today called the spiritual need. Inner peace is everyone's need. Faith, according to Zakiah Darodjat, gives religious individuals with inner relief. Mental wellness is built on a foundation of relief and inner serenity. Every believer will not be confused or scared if the subject of faith is studied and applied in dealing with life's issues.

\section{The Meeting Point between Psychology and Maqashid Al-Shari'ah}

Humans fulfill basic needs, such as the urge to pursue life objectives, in every activity they engage in. A Human in this context is a complete human/insan kamil physically and spiritually, and psychologically, or whether as an individual, a creature

18 Al-Syatibi.

19 Iffatin Nur, Syahrul Adam, dan M. Ngizzul Muttaqien, "Maqāșid Al-Sharīat: The Main Reference and Ethical-Spiritual Foundation for the Dynamization Process of Islamic Law," AHKAM : Jurnal Ilmu Syariah 20, no. 2, diakses 10 Juni 2021, https://doi.org/10.15408/ajis.v20i2.18333.

20 Idi Warsah, "Dimensions Of Soul In The Quran: An Islamic Psychological Perspective," Akademika, 2020, 25, no. 02 (Desember): 295-314, https://doi.org/DOI: https://doi.org/10.32332/akademika.v25i2.2029.

${ }^{21}$ Muhammad Naquib Al-Attas, Prolegomena To The Metaphysics Of Islam: An Exposition Of The Fundamental Elements Of Worldview Of Islam, (Kuala Lumpur: International Institute of Islamic Thought and Civilization, 2001).

22 Ismail Raji al-Faruqi dan Lois Lamya al-Faruqi, Atlas Budaya Islam: Menjelajah Khazanah Peradaban Gemilang (Bandung: Mizan, 2002).

23 Shihab Quraish, Lentera hati: kisah dan hikmah kehidupan, (Bandung: Mizan Pustaka Utama, 2007):19.

24 Stephen R. Covey, First Things First (New York: Free Press, 2003). 
of God, social being, or human being essentially and existentially ${ }^{25}$. The objective of human existence, according to Maqashid al-Shari'ah, is to achieve advantages through the application of Sharia in the form of obeying instructions and avoiding prohibitions. To acquire well in this world and the next, all life actions that produce advantage as described by sharia must be accompanied by religious obligations ${ }^{26}$. Benefits/mashlahah are divided into three degreeses by Imam al-Syatibi: primary needs/dharuriyat, secondary needs/hajiyat, and tertiary needs/tahsiniyat.

The first level, dharuriyat needs are basic requirements that must be met. If this level of need cannot be realized, then the safety of mankind will be threatened both in this world and in the hereafter. According to al-Syatibi, five things come under this category, namely maintaining religion/hifdhu al-din, maintaining the soul/hifdhu alnafs, maintaining reason/hifdhu al-'aql, maintaining descendants/hifdhu al-nasl, and maintaining the property/hifdhu al-maal) ${ }^{27}$.

The second category, hajiyat needs is secondary demands that, if not met, do not pose a threat to safety but can cause difficulties. All of these issues are resolved by Islamic law. The establishment of the leniency/rukhshah law, which allows to do jamak and congregational prayers while traveling, is an example of Islamic law's care for this need. The third level of needs, tahsiniyat needs are those that, if not met, do not jeopardize the existence of any of the five criteria above or cause issues because this category of need is a complement to propriety based on conventions that are morally demanding.

The achievement of these benefits is a driving force for the implementation of sharia ${ }^{28}$. In a psychological sense, Maqashid theory emphasizes the same thing as motivation theory, namely human needs ${ }^{29}$. From a psychological standpoint, motivation theory formulates the primary demands of humans in obtaining the benefit for themselves in the world and the hereafter based on Sharia values. In the meantime, according to Maqashid al-Shari'ah, motivation is essentially the wisdom or purpose of Islamic law, which was revealed by Allah for the benefit of mankind in this world and the next. As a result, the psychological view and Maqashid al-Shari'ah have a point of convergence in terms of human benefit.

The benefit is expressed in five fundamental needs from a psychological standpoint, the fulfillment of which is achieved on a priority scale, in the sense that if all of one's requirements are not filled at the same time, the fulfillment of the most fundamental requirements takes precedence. The five basic needs are explained into do following pool: Physiological Needs, which are the main and essential requirements connected to human biological activities such as the need for food, clothes, and shelter, physical health, sex needs, others; Safety Needs, which include the need for protection from numerous dangers and diseases, as well as poverty, starvation, and unjust treatment; Social Needs, such as the needs to be accepted, loved, and acknowledged in friendship. If this need is not addressed, mental health issues may arise; Esteem Needs, which include needs to be respected and recognized. The satisfaction of this need will result in self-assurance and prestige; Self-Actualization Needs, which include the need

${ }^{25}$ Abdurrahman, "Teori Maqasid Al-Syatibi Dan Kaitannya Dengan Kebutuhan Dasar Manusia Menurut Abraham Maslaw," Al-Fikr, 22 No. 1, 2020, : 52-70.

26 Abdurrahman,.

27 Sardiman A. M, Interaksi Dan Motivasi Belajar Mengajar (Jakarta: PT Raja Grafindo Persada, 2004): 73-74.

${ }^{28}$ Abdurrahman, "Teori Maqasid Al-Syatibi Dan Kaitannya Dengan Kebutuhan Dasar Manusia Menurut Abraham Maslaw," Al-Fikr, 22 No. 1, 2020, : 52-70.

${ }^{29}$ Abdurrahman,. 
to be empowered by one's potential and ability. This is the most pressing level ${ }^{30}$. Meanwhile, in the Maqashid al-Shari'ah perspective, the benefits are formulated in three levels of priority scale as described, namely Maslahah Dharuriyat, Hajiyat and Tahsiniyat.

\section{E. Religious, Domestic and Social Ritual Activities of Retirement Community}

In the case of respondent Mr. H. Ah, BA, when he entered retirement age, he saw this as a perfect chance for religious ritual worship. This is because, according to him, there were no longer any normal or hectic activities, as there were while he was on duty. His worship spirit was strong, and he tried to be able to lead congregational prayers as an imam at a mosque near his home in his everyday life. Additionally, he enjoyed performing night prayers. He can also still fast for the entire month of Ramadan, as well as some sunnah fasting, depending on his health. Reading the Qur'an is a daily practice for him, and he even educated his congregation to do so. He is also diligent in reading religious books. The peak of religious rituals that he felt the happiest was at the time of performing the pilgrimage ${ }^{31}$.

Individual religious maturity, especially in terms of dedication to ritual worship, has developed along with maturity in old age, where religious individuals increasingly realize the truth of life after death. This is consistent with Maslow's theory of needs in Humanistic psychology, which states that once an individual has met his or her need for self-actualization, the next step is to meet the E-need (need for self-existence), which is the fulfillment of a sincere religious desire. This is a motivation when viewed through the lens of psychology and Maqashid al-Shari'ah.

The respondent, $\mathrm{H}$. Na, S.Pd, believes that being a retiree did not make him feel lonely because he was previously a devout follower of his faith (Islam). As a result, during his retirement, his reverence grows as he understands that he is becoming old and approaching death. He attends congregational fardhu prayers in the mosque in front of his home every day, as well as sunnah Dhuha and Tahajjud prayers, recitation of the Qur' an, and reading religious publications. After the journey, the intensity of his ceremonial worship grew by up to double. Everything he undertakes in his old age, he claims, is for the sake of the world and the hereafter ${ }^{32}$.

From this description, it can be deduced that what the respondent felt, experienced, and did is a mature level of religious commitment in the field of ritual, with strong ideological roots (faith) inherited from the family and bolstered by a good educational background and supportive family environmental factors. In terms of Psychology and Maqashid al-Shari'ah, the objective of gaining the benefit of the world and the hereafter is a motivation. The responder, who is also a teacher, is a well-known personality in his community, and he is well-respected by his colleagues. This aspect inspires him to improve his spiritual life.

Being a retiree does not impose a major psychological strain for respondent Mr. $\mathrm{H}$. As, $\mathrm{SH}$, his religious rituals have also improved in quality. He had previously been renowned as an ardent follower of God. He was renowned as a religious expert in his workplace setting while he was still active in the ministry, and he was frequently invited to offer sermons and talks. His days are now filled with religious rituals such as congregational fardhu prayers at the mosque, sunnah prayers such as Tahajjud and Dhuha, fasting, reading the Qur'an, teaching the Qur'an, and reading religious

\footnotetext{
30 Abraham H Maslow, Motivation and Personality (New York: Longman, 1987):15-22.

31 H Ah, The Dinamics Spirituality and Social, 26th June 2018.

$32 \mathrm{H} \mathrm{Na}$, The Dinamics Spirituality and Social, 29th June 2018.
} 
literature to expand his religious understanding 33 .

The respondent Mr. Su, who retired in 1999, felt that being retired means:

It's time to organize yourself, your emotions, your sentiments, your body, and your family, sir, so that you can be at peace now that you're not chasing work anymore. Nothing else is on my mind, and I'm not being given any commands. It's much better if all you do is worship. I believe I still lack religious understanding and resources ${ }^{34}$.

As an old devoted Muslim, he prefers to stay at home with his loving wife to do fardhu prayer (most commonly at the al-Muhajirin mosque), which is the nearest mosque to his home. He also enjoys listening to recitations on the radio or watching recitation lectures on television. He discovers the meaning of religious life that is unique, beautiful, serene, and reassuring as the administrator of the mosque/takmir and an engaged congregation. Su has a morning routine that includes a healthy walk to keep a healthy physique, in addition to worship and social events. It is very different from when he was rushing to go to work.

What Mr. As and Mr. Su went through in terms of the intensity of ritual worship is extremely pertinent to the notion of Logo therapy, which is about living a meaningful life, which is the foundation and pillar of mental health for people in the form of a serene, tranquil, and calm existence. Of course, this is more intense for elderly individuals, who in this instance are retirees, who have completed issues and daily chores that deplete physical and mental vitality. It was because $\mathrm{Mr}$. Su as a retiree (and retirees in general) ideally indicated that he had arrived at the maximum level of self-actualization in the hierarchy of needs for the ordinary person while still working. Thus, the hierarchy of achieving existential needs (E-Needs), which are more spiritual in character and transcendental spiritual, is the next step. The respondents, As and Su, engage in a variety of religious, social, and sporting activities in order to achieve their own welfare in terms of worldly and ukhrowi safety, which includes dharuriyah needs such as religious benefits/mashlahah al-diniyah, property benefits/mashlahah al-maliyah, reason benefits/mashlahah al-aqliyah, soul benefits/mashlah al-nafsiyah, and descendant benefits/mashlahah al-nasliyah.

Mr. Sds mentioned that there are unique methods to acquire peace of mind and spirit when facing and responding to retirement, according to him, such as conducting congregational fardhu prayer, night prayer, dhuha prayer, praying for hajat, and tawakal. Aside from that, sticking to God's principles, praying for His guidance frequently, and avoiding doing things outside of His resources are also essential for a stable life. As a result, it is critical to think optimistically and trust that everything will turn out OK. "Don't be envious, discuss positive things, and compete in good deeds", is the additional suggestion ${ }^{35}$.

Mr. H. Bkr, M.Ed experienced dramatic growth in his religious attitude after entering retirement. He completed both compulsory and Sunnah acts of worship. In the realm of prayer, he is always punctual and prays in congregation at either the mosque where he resides or the mosque where he is involved. Similarly, he enjoys performing the Shalatul Lail, or midnight prayer. He claims that he gets up at 3 a.m. every night to perform the tahajjud and hajat prayers. The time is spent by reciting the Qur'an while waiting for the dawn to arrive. Similarly, he always reads the Qur'an during the interval between Maghrib and Isha prayers. In terms of fasting, in addition to Ramadan, Bkr fasts regularly on Mondays and Thursdays, as well as other sunnah

\footnotetext{
${ }^{33} \mathrm{H}$ As, The Dinamics Spirituality and Social, 27- 28 $8^{\text {th }}$ June 2018.

$34 \mathrm{Su}$, The Dinamics of Spirituality and Social, 26th June 2018.

35 Sds, The Dinamics Spirituality and Social, 5 th Agustus 2018.
} 
fasts like Shawwal, Muharram, and others. Bkr said that such devotional activities were not carried out while he was still working for an organization. He only did obligatory worship while still on duty, such as fardlu prayer, which was sometimes too late ${ }^{36}$.

Even though Mr. Smw, had reached his retirement time, he did not appear to be interested in performing worship. He continues to show his neighbors that he is still busy. Mr. Smw has stated on several occasions, "Actually, I have retired, but I still require my energy, and I am continually prolonging my working duration". Mr. Smw always leaves the house to give the impression that he is still on duty to back up his claim. Meanwhile, according to Sds, his neighbors claimed that he had retired.

Theoretically, what appears in the religious ritual behavior of retired employees can be explained and analyzed as follows: religious life in the elderly has reached a level of stability; there is an increased tendency to accept religious opinions; there is a more serious acknowledgment of the reality of the afterlife; religious attitudes tend to lead to mutual needs, and love between the elderly; religious attitudes tend to lead to mutual needs, love between the elderly; this fear of death has an impact on increasing the formation of religious attitudes and beliefs in the existence of eternal life. According to the concept of Maqashid al-Shari'ah, the growth of these six things is primarily aimed at the realization of mental health and the attainment of self-benefit in order to get the world's and hereafter's safety ${ }^{37}$.

In terms of family household activities, the retired respondents generally performed light regular chores such as cleaning furniture, gardening, raising grandkids, light exercise, raising chickens on a small scale, and so on. These activities are more of a form of enjoyment than an economically productive firm with an income turnover goal. Small yet significant things in life, light, and enjoyment can help older persons retain their mental health. And the activities that retirees engage in at home are very much in line with this theory.

As Javanese, retirees are generally active in community activities such as RT/RW administrators, mosque congregations/takmir, family gatherings or certain associations, as well as community association activities such as attending wedding receptions, visiting sick people, and so on. However, many of these social activities need money, which is an issue for retirees. However, for them, this is not the most serious issue. It can be deduced from this explanation that the importance of balance among physical, psychological, social, and spiritual components as a deciding factor for mental health is important so that people may live in harmony and prevent societal disputes that can lead to inner strength and individual souls. Moreover, as community leaders (adoptive opinion leaders), social activity is an important role that society respects.

\section{F. Spiritual Strengthening Factors of Retirement Community}

Retirement may cause various problems because not everyone is ready to face it. Retirement will stop someone's long-standing habitual activities. In addition, retirement will cut a number of social statuses that have been built and cultivated with coworkers for years. The most important is the loss of one's long-held identity that had existed for a long time.

${ }^{36}$ M.Ed Bkr, The Dinamics Spirituality and Social, 08 ${ }^{\text {th }}$ August 2018.

37 Layla Takhfa Lubis dkk., "Peningkatan Kesehatan Mental Anak dan Remaja Melalui Ibadah Keislaman," Al-Hikmah: Jurnal Agama dan Ilmu Pengetahuan 16, no. 2 (16 Oktober 2019): 120-29, https://doi.org/10.25299/jaip.2019.vol16(2).3898. 
In this context, a retired respondent, Bkr, stated that during his initial months of retirement, crossing the road in front of his workplace gave him a peculiar feeling, therefore he avoided crossing the road that went by his workplace ${ }^{38}$, while the retiree of the Sidomukti sub-Regional district's Secretariat felt relieved as soon as he began his retirement term. He felt like he was chasing each other between community issues, office duties, and domestic concerns when he was still at the workplace. The burden, on the other hand, has been lightened since retirement. He just focuses on social and domestic affairs ${ }^{39}$.

In terms of how Bkr and Sds reacted to retirement, there was a distinction. After retiring, Sds did not experience any psychological distress; rather, he believed that his burden has been reduced. Meanwhile, Bkr's mental stability deteriorated as he approached retirement. There are various aspects that influence how Bkr and Sds react to retirement, but in the end, Bkr was able to overcome his mental tension as a result of his impending retirement. These differences are due to the following factors. The first is the level of activity before retirement. Bkr did not have a lot of social activities in the community during the service term. The distance between Bkr's workplace and his house was the reason for his lack of social activity. Meanwhile, Sds worked in Salatiga City, where he resides, from his high appointment till retirement. He participates in a variety of social and religious activities. He has held some positions in the community, including RW chairman, City Community Empowerment Institute (LPMK) chairman, mosque administrator, and Majlis Ta'lim Management. In addition, he is a regular attendee at the mosque's prayer activities. The second is spirituality factor before retirement. Bkr did not participate in spiritual activities such as zikr assembly and majlis ta'lim (learning assembly) while he was still working. Sds, on the other hand, is constantly involved in different zikr and shalawat assemblies during his service time. Bkr's soul began to stabilize after actively participating in several majlis ta'lim, such as the Salatiga retired family's majlis ta'lim, the Abu Dahlan recitation, the al-Ma'la mosque's Sunday Morning recitation, and the recitation of the Indonesian Hajj Brotherhood Association.

In the case of $\mathrm{H}$. Ah, BA, the coming of retirement and advancing age has solidified his faith, particularly his self-belief in the unseen and life after death. He was more at ease and earnest when it came to religious rites. It grew much more intense when he completed the pilgrimage. For him, the world's life appears to have come to an end, which implies he no longer wants to pursue worldly interests. He imitated the custom of a Javanese monarch who had stepped down from his throne by saying, "Lengser keprabon, mungkur Kacanyan, madeg pandhito". Furthermore, as a result of the regular incidence of minor health issues, worldly aspirations become weaker. According to his last son (MB), Mr. H. Ah, BA, frequently suffers from diabetes and must be cautious in his activities and eating habits. The sickness, on the other hand, did not discourage him and even motivated him to conduct more worship and good deeds. His kind demeanor, which made it easier for him to help others and form friendships to gather with people at religious and assembly events brightened and strengthened his spirit. This is in line with the sociability theory, which claims that people who engage in more self-socialization are healthier than people who prefer to be alone.

Mr. H. Na, S.Pd, the respondent who retired as Head of MTsN in 2007, has grown spiritually and matured by self-study, reading a large number of self-taught religious books, and participating in study forums. Internalization of spiritual values

\footnotetext{
$38 \mathrm{Bkr}$, Spiritual Strengtening Factors of Retirement Community, 08, August 2018.

39 Sds Mr, Spiritual Strrengtening Factors of Retirement Community, 19th August 2018.
} 
was achieved through religious rituals such as fardhu prayer, sunnah (tahajud, dhuha), pilgrimage twice, sunnah fasting, almsgiving, prayer, reading the Qur'an, caring for orphans at the Orphanage, waqf of land and buildings for Islamic educational institutions near his home, and socio-religious activities in one of the religious organizations. He even becomes a member of the leadership of the religious organization for several periods at the Semarang Regency level. As he grows older, his spiritual activities become more focused on studying the substance of the Qur'an at the al-Muhajirin mosque in his village (Candirejo Indah Residence) on Wednesday nights and at the Al-Falah Mosque in Candirejo on Sunday morning ${ }^{40}$ with his loving wife.

The respondent, Mr. H. Sbd, S.Pd, started working for the government in 1976 and left in 1998. He began his civil service career in 1976 with a Bachelor's Degree (BA) and completed it in 2002. As a retiree from an Islamic state higher education institution, he is highly diligent in carrying out religious teachings, both fardhu, and sunnah, such as prayer, fasting, alms, and so on. Mr. Sbd, S.Pd, appears to like reading books, particularly religious works, based on the display cabinet in the living room. "Yes, I think that by reading these books, I will be able to improve my understanding of religion", he stated, adding that it is because he did not attend religious schools madrasah or Islamic boarding schools ${ }^{41}$.

Every Sunday morning, Mr. Sbd, S.Pd, as a person of increasing maturity and experience, actively engages in Islamic studies activities at the Candirejo Tuntang alFalah mosque ${ }^{42}$. Mr. Su, who is also a member of the congregation, participates in the study of the Qur'an's interpretation every Wednesday night in the Candi Indah residential mosque, which is also taught by an IAIN Salatiga lecturer. He said:

By studying the substance of the Qur'an, I believe I have obtained information that is extremely beneficial to my life. It turns out that I have missed a lot of years since I have not studied the Qur'an's contents. I feel a meaningful, happy, and peaceful life when I am close to the Qur'an ${ }^{43}$.

Mr. H. Sbd, S.Pd, is also a religious social activist. He has worked as a secretary and administrator for a religious organization's Tuntang branch for several years. He also looks after an orphanage in his neighborhood. Mr. H. Su, S.Pd, can feel and enjoy a meaningful and joyful life in his later years by participating in numerous activities, and he may be beneficial to society and others. As the orphanage's caretaker, he also assisted many neighbors who could not afford to complete their schooling by registering them to enter the institution ${ }^{44}$.

In terms of religion psychology, what happened and was experienced by $\mathrm{Mr}$. $\mathrm{H}$. $\mathrm{Na}$, S.Pd, and H. Su, S.Pd, is consistent with Viktor W. Frankel's Logo therapy theory, which claims that the key to health and happiness in life is the amount to which individuals feel the meaning of their lives for others. All of this is accomplished by a variety of actions, including leading a healthy lifestyle, keeping one's heart and feelings, hard work, a desire to help others and make friends, optimism, gratitude, and becoming closer to God.

Mr. H. As, SH, the respondent, is a retired Semarang regency government employee. He had served as the sub-district chairman in various Semarang subdistricts until retiring in 2003. He is a clean, honest, and extremely active individual

\footnotetext{
${ }^{40} \mathrm{Na}$, The Dinamics Spirituality and Social, $20^{\text {th }}$ of June 2018.

${ }^{41}$ Sbd, Spritual Strengtening Factors of Retirement Community, 25th June 2018.

$42 \mathrm{Sbd}$.

${ }^{43} \mathrm{H} \mathrm{Su}$, Spirituality Strengtening Factors of Retirement Community, 25th June 2018.

${ }^{44} \mathrm{Sbd}$, Spirituality Strentgtening Factors of Retirement Community.
} 
who is involved in a variety of social and religious activities. He finds purpose in the dynamics and spiritual experiences through performing fardhu/sunnah prayers and fasting, reciting the Qur'an while understanding its meaning, fasting, almsgiving, and assisting others. In his old age, these are the sources of his happiness and mental wellness ${ }^{45}$.

Mr. H. As, SH, is very strict in religious affairs which is the core of human spirituality to live a meaningful life. Religion and worship became the center of his life's focus. His devotion to religion and spiritual principles appears to be reflected in his efforts to instill them in his children and grandchildren. He is also devoted to sharing knowledge and ideas of a clean, bright, advanced, and pious life as a preacher. $\mathrm{He}$ is also the chairman of the mosque/takmir of the Soba housing complex near his home in Tapen, Tuntang, demonstrating his Islamic social leadership. Simultaneously, it proves the validity of the theory that a person with a strong religious spirituality who enters the post-power phase (becoming a pensioner) retains an important social religious function in society and continues to enjoy satisfaction by serving the community. Even the nature of spirituality and religious maturity intensifies as an individual's age advances and the day of death approaches ${ }^{46}$.

$\mathrm{Mr} . \mathrm{Su}$ is a retired police officer who lives in Jombor, Tuntang, Semarang. He is gentle, kind, courteous, humble, and dedicated to performing congregational prayers at the al-Muhajirin mosque as a place for electrifying the clarity of his spiritual soul as an older person. He understood that his religious knowledge of Islam was still relatively limited. As a result, he is always there as a participant in the weekly study of the Qur'an's content on Tuesdays and Wednesdays. He also wants to set a positive example for the younger ones in the neighborhood by continuing to study religion even though they are getting old.

$\mathrm{Mr}$. Su realized that his religious practice was still small, but he did everything seriously, gladly, and gratefully, including praying cheerfully, fasting happily, and attending regular lectures with enthusiasm. Mr. Su has significant and joyful experiences in life as an elderly person by getting closer to Allah, seeking forgiveness, thanking Allah, performing many prayers, being grateful for the benefits, being patient for disasters such as being unwell and being able to help others. He enjoys the art of wayang as a Javanese because it has numerous stories that serve as positive inspirations to living life as a person who is straight and honest in dealing with oneself, God, and others ${ }^{47}$.

In terms of spiritual strengthening based on social values, $\mathrm{Mr}$. Su is a wellrespected personality in his community for a variety of reasons. First and foremost, he is a former figure of the housing complex. The second is that he is a retired police officer with a relatively high rank (at the level of a mid-level officer) and a solid public image. Third, he wants to engage in all socio-religious activities with the local community, such as community service, social gatherings, religious lectures, mosque construction, and so on. To summarize, Mr. Su is worthy of being a role model, particularly for the younger generation ${ }^{48}$. Mr. Su lives a fulfilling and happy life because he is actively involved in the community. "I feel beneficial for others. May it be

45 As, The Dinamics Spirituality and Social.

46 Handayani dan Oktaviani, "Hubungan Spiritualitas dengan Depresi Lansia di Panti Sosial TResna Werdha (PSTW) Sabai Nan Aluih Sicincin," Jurnal Endurance, 2018, 3, no. 1 (15 Agustus 2017): 14-24, https:/ / doi.org/Indonesia.

$47 \mathrm{Su}$, Spirrituality Strengtening Factors of Retirement Community.

48 Takarina, Spirituality Strengtening Factors of Retirement Community, 30th June 2018. 
good deeds in the hereafter", this is his good hope for society ${ }^{49}$.

What $\mathrm{Mr}$. Su experienced and did reflects the achievement of mental enlightenment, spiritual enlightenment in which individuals experience positive mental development with the emergence of clear, happy emotion/inner conditions, positive social behavior, and stable emotions in living the dynamics of life. Meanwhile, from the perspective of Maqashid al-Shari'ah, it means that Mr. Su has met his primary needs/dharuriyah in the form of values, which are the actualization of the essential content of Islamic teachings such as recommendations for shabr, tawakkal, gratitude, sincerity, ridha, qana'ah, ta'awun, and so on in order to achieve inner peace and afterlife happiness ${ }^{50}$. Based on the data, it can be inferred that the retired community, who are all old, with an average age of over 70 years, are motivated by acknowledgment and gratitude from their environment for their efforts while serving in various social roles in their community. This contributes to their spiritual development.

\section{G. Conclusion}

Previous research has shown that post-retirement work factors and gender are determinants of depression levels/Post Power Syndrome, whereas the findings of our study show that various backgrounds that cause religious attitudes in the retirement community also provide an overview of the dynamic characteristics of their spirituality /as well as religiosity. The religious features of the retired community are summarized as follows: Religious life in old age has stabilized and increased tendency to accept religious opinions.

Internal aspects such as piety rituals, religious appreciation, a good educational background, good employment and career (such as teacher and madrasah supervisor), and quiet, harmonious, and religious family conditions are pillars of strong and healthy spirituality for individuals. Furthermore, extrinsic variables such as the absence of social conflicts and the real gratitude and respect of the surrounding community for individuals' long service and example (social devotion and leadership) contribute to the spiritual power of individuals in old age. This is consistent with the spiritual development paradigm, which includes internal emotional, intellectual, and psychological components as well as external social and cultural aspects. In terms of social activities, after retirement, social activities have exploded. This is linked to the need for self-sufficiency as well as environmental acceptability and respect.

The link between the psychological concept and Maqashid al-Shari'ah is that both place benefit as the central goal of human activity. The benefit in the perspective of psychology formulates five basic needs, namely physiological needs, security, social, appreciation, and self-actualization, whereas benefit in the Maqashid al-Shari'ah perspective is focused on the maintenance of religion, reason, soul, property, and descendants which briefly leads to the benefit of the world and the hereafter. The achievement of benefit, which is the purpose of all human effort, is the motivation in all activities, according to both psychology and Maqashid al-Shari'ah. Then, in terms of psychology and Maqashid al-Shari'ah, the benefit is gained by meeting basic needs using a priority scale that is divided into three tiers, namely Maslahah Dharuriyat, Hajiyat, and Tahsiniyat.

${ }^{49} \mathrm{Su}$, Spirituality Strengtening Factors of Retirement Community.

50 Abdurrahman, Abdurrahman, "Teori Maqasid Al-Syatibi Dan Kaitannya Dengan Kebutuhan Dasar Manusia Menurut Abraham Maslaw," Al-Fikr, 22 No. 1, 2020, : 52-70. 


\section{REFERENCES}

A. M, Sardiman. Interaksi Dan Motivasi Belajar Mengajar. Jakarta: PT Raja Grafindo Persada, 2004.

Abdurrahman, Zulkarnain. "Teori Maqasid Al-Syatibi Dan Kaitannya Dengan Kebutuhan Dasar Manusia," t.t., 19.

- - - "Teori Maqasid Al-Syatibi Dan Kaitannya Dengan Kebutuhan Dasar Manusia," t.t., 19.

Ah, H. Dinamika Spiritualitas dan Sosial, 26 Juni 2018.

Al-Attas, Muhammad Naquib. Prolegomena To The Metaphysics Of Islam: An Exposition Of The Fundamental Elements Of Worldview Of Islam,. Kuala Lumpur: International Institute of Islamic Thought and Civilization, 2001.

'Al-Fasi, 'ilal. Maqashid al-Syari'ah al-Islamiyah wa Makarimuha. Maroko: Mathba'ah alRisalah, 1979.

Al-Syatibi, Abu Ishaq. al-Muwafaqat fi Ushul al-Syariah. 1. Beirut: Dar al-Ma'rifah, 1996.

As, H. Dinamika Spiritualitas dan Sosial, 27 Juni 2018.

Bkr. Faktor-Faktor Penguatan Spiritual Pensiun, Agustus 2018.

Bkr, M.Ed. Dinamika Spiritualitas dan Sosial, Agustus 2018.

Creswell, John W. Qualitative Inquiry and Research Design Choosing Among Five Tradition. London: Sage Publication, 2007.

Handayani, Reska, dan Eci Oktaviani. "Hubungan Spiritualitas dengan Depresi Lansia di Panti Sosial TResna Werdha (PSTW) Sabai Nan Aluih Sicincin." Jurnal Endurance, 2018, 3, no. 1 (15 Agustus 2017): 14-24. https:/ / doi.org/Indonesia.

Ismail Raji al-Faruqi dan Lois Lamya al-Faruqi. Atlas Budaya Islam: Menjelajah Khazanah Peradaban Gemilang. Bandung: Mizan, 2002.

Jaladuddin. Psikologi agama. Jakarta: Rajawali Grafindo Persada, 2012.

Lesmana, Danar. "Kecerdasan Spiritual Dengan Kecemasan Menghadapi Masa Pensiun." JIPT: Jurnal Ilmiah Psikologi Terapan, Januari, 02, no. 1 (2014): 16.

Lubis, Layla Takhfa, Laras Sati, Naura Najla Adhinda, Hera Yulianirta, dan Bahril Hidayat. "Peningkatan Kesehatan Mental Anak dan Remaja Melalui Ibadah Keislaman." Al-Hikmah: Jurnal Agama dan Ilmu Pengetahuan 16, no. 2 (16 Oktober 2019): 120-29. https:// doi.org/10.25299/jaip.2019.vol16(2).3898.

Majma' al-Lughah al-'Arabiyyah al-Mu'jam al-Wasith. Istanbul: Al-Maktabah al-Islamiyah, t.t.

Maslow, Abraham H. Motivation and Personality. New York: Longman, 1987.

Mr, Sds. Faktor-Faktor Penguatan Spiritualitas Pensiunan, Agustus 2018.

Muhammad al-Thahir, Ibn 'Asyur. Maqashid Al-Syari'ah Al-Islamiyah. Tunisia: Mashna' Al-Kitab, t.t.

Muhammad, Jamaludin Ibn Al-Mukarram Ibn al-Manzur. Lisan Al Arab. 10. Mesir: al$\mathrm{Mu}^{\prime}$ assasah al-Misriyyah al-'Ammah li al-Ta'lif wa al-Anba' wa al-Nashr, t.t.

Muzakkir. "Kesiapan Diri Menghadapi Masa Pensiun Ditinjau Dari Aspek Spiritual." Al-Kaffah-Jurnal Kajian Nilai-Nilai Keislaman 8, no. 1 (t.t.): 1-27.

$\mathrm{Na}, \mathrm{H}$. Dinamika Spiritualitas dan Sosial, 29 Juni 2018.

Nejdet, Deleyner. "Religious Contrasts in Consumer Decision Behaviour Patterns: Their Dimensions and Marketing Implications." European Journal of Marketing 28, no. 5 (t.t.): 36-53.

Nur, Iffatin, Syahrul Adam, dan M. Ngizzul Muttaqien. "Maqāṣid Al-Sharīat: The Main Reference and Ethical-Spiritual Foundation for the Dynamization Process 
of Islamic Law." AHKAM: Jurnal Ilmu Syariah 20, no. 2. Diakses 10 Juni 2021. https:// doi.org/10.15408/ajis.v20i2.18333.

Putri, Finna Dwi, Amel Yanis, dan Elmatris Syamsir. "Prevalensi Depresi pada Pensiunan Pegawai Negeri Sipil yang Mengambil Dana Pensiun di Bank BTPN Cabang M. Yamin Padang." Jurnal Kesehatan Andalas 4, no. 2 (1 Mei 2015). https:// doi.org/10.25077/jka.v4i2.258.

Qatan, Manna al-. Tārikh al-Tasyri' al-Islami. Beirut: Mu'assasat al-Risalah, 1996.

Quraish, Shihab. Lentera hati: kisah dan hikmah kehidupan,. Bandung: Mizan Pustaka Utama, 2007.

R. Covey, Stephen. First Things First. New York: Free Press, 2003.

Santrock, J.W. 2002. Perkembangan Masa Hidup. Jakarta: Erlangga, t.t.

Sbd. Faktor-Faktor Penguatan Spiritualitas Pensiunan, 25 Juni 2018.

Sds. Dinamika S[iritualitas dan Sosial, Agustus 2018.

Su. Dinamika Spiritualitas dan Sosial, 26 Juni 2018.

Su, H. Faktor-Faktor Penguatan Spiritualitas Pensiunan, 25 Juni 2018.

Syalabi, Muhammad Mustafa al-. al-Madkhal fi al-Ta'rif bi al-Figh al-Islāmi. Beirut: Dar alNahdhah al-'Arabiyyah, 1983.

Takarina. Faktor-Faktor Pengutaan Spiritual Pensiunan, 30 Juni 2018.

Warsah, Idi. "Dimensions Of Soul In The Quran: An Islamic Psychological Perspective." Akademika, 2020, 25, no. 02 (Desember): 295-314. https://doi.org/DOI: https:// doi.org/10.32332/akademika.v25i2.2029. 
AKADEMIKA: Jurnal Pemikiran Islam

Vol. 26, No. 01 Januari - Juni 2021 